\title{
Imaginarios del progreso. Representaciones tecnológicas en el Circuncaribe mediante tarjetas postales (1899-1930). El caso de Costa Rica
}

\section{Imaginary of progress. Technological representations in the Circuncaribe through postcards (1899-1930). The Costa Rican Case}

\author{
Enrique Camacho Navarro ${ }^{1}$
}

\begin{abstract}
Resumen
El objetivo de este texto es analizar algunos vestigios visuales, tales como lo son las tarjetas postales vinculadas al tema de las plantaciones circuncaribeñas del banano, atendiendo de manera particular el caso costarricense. Luego de realizar una lectura iconológica, presentar el tipo de discurso que de ellas emana, sosteniendo como tesis que, a través de las imágenes en las que se destaca el adelanto tecnológico mediante la iconografía de barcos y ferrocarriles, se construye un imaginario de prosperidad y bonanza, que sería la propuesta/el objetivo de las compañías bananeras, instaladas en una extensa región bañada por el Mar Caribe, entre finales del siglo XIX y principios del siglo XX.
\end{abstract}

Palabras clave: Circuncaribe; Costa Rica; Postales fotográficas;Iconología; United Fruit Company; Imágenes del progreso

\begin{abstract}
The aim of this text is to analyze some visual evidence, such as postcards linked to banana plantations in the Circuncaribbean area, paying special attention to the Costa Rican case. After an iconological reading, it follows a presentation of the type of discourse that emanates from them, arguing that through the images an imaginary of prosperity and bonanza is built, which would be the proposal of the banana companies that, between the end of the 19th Century and the beginning of the 20th Century, settled in an extensive region bathed by the Caribbean Sea.
\end{abstract}

Keywords: Sustainable Development; Sustainable Production and Consumption; Pollution; Urban Metabolism.

Tipología: Artículo de investigación

Recibido: $28 / 02 / 2018$

Evaluado: $7 / 04 / 2018$

Aceptado: $27 / 07 / 2018$

Disponible en línea: 30/08/2018

Cómo citar este artículo: Camacho-Navarro, E. (2018). Imaginarios del progreso. Representaciones tecnológicas en el Circuncaribe mediante tarjetas postales (1899-1930). El caso de Costa Rica. Jangwa Pana, 17(3), 318-341. Doi: http:// dx.doi.org/10.21676/16574923.2544

1. Ph.D. Estudios Latinoamericanos. Investigador Titular "C" de Tiempo completo en el Centro de Investigaciones sobre América Latina y el Caribe (CIALC), de la Universidad Nacional Autónoma de México (UNAM). Correo electrónico: camnav@unam.mx. ORCID ID: 0000-0001-8622-9612 


\section{INTRODUCCIÓN}

\section{Intereses bananeros en el Circuncaribe}

$\mathrm{E}^{\mathrm{n}}$ 1899 se fundó la United Fruit Company (UFCo), que luego sería conocida también como "la bananera" (Mena, 1972), "la frutera" (Ricord, H. E. 1974), la UFCo, "el pulpo" (Handy, 1996), "la compañía", o coloquialmente reconocida en la región circuncaribeña con el nombre de "la yunai", denominación que proviene de la referencia del United en inglés, pero pasado al español, y que en su momento da origen al título usado por la novela del costarricense Carlos Luis Fallas: Mamita Yunai (Fallas, C. L. (1941). Aquella empresa, transnacional por excelencia, con la intención de explotar la riqueza agroexportadora, fijaría sus actividades productivas y de comercialización en territorios que comprendían la zona atlántica de Centro y Norte América, las West Indies, así como vinculada de manera muy directa con algunas zonas de los Estados Unidos de Norteamérica y de México. Considerado como el Circuncaribe, este territorio fue el campo de acción de las actividades agroexportadoras a las que se dedicó con intensidad inusitada hasta 1930, y que continuaría en algunos países, de manera particular, hasta nuestros días.

Dentro de ese periodo, e instalada en esa geografía, continuando una tradición que se había iniciado en la última década del siglo XIX, una de las actividades de relieve llevada a cabo por la firma comercial fue la elaboración de desmedidas cantidades de propaganda, anuncios periodísticos, tarjetas postales, libros, etcétera, todo lo anterior ligado a la actividad comercial y turística que ella misma practicaba entre varios puntos de los países de la región y los Estados Unidos. Los mismos mapas fueron parte de esa parafernalia en la que se reflejaban los intereses inherentes a la compañía. Gracias a la lectura visual de ellos (Black, 1998), y como se puede entender al analizar en detalle un mapa de 1909 que identifica las líneas puntuadas que están delineando las rutas marítimas que seguían las embarcaciones de la White Fleet entre los puertos estadounidenses y los circuncaribeños, puede interpretarse en su contenido la visión de dominio que la United Fruit Company manifestaba hacia lo que fue concebido por los inversionistas estadounidenses como "su patio trasero". (Figura 1. Mapa del Circuncaribe elaborado por la UFCo) El conjunto de ese tipo de vestigios constituyó una propuesta iconográfica que influiría en la mirada que desde el imperio se tuvo del área centroamericana y caribeña. En medio de ese mundo de imágenes, tuvieron una presencia sobresaliente las tarjetas postales. Aparecieron artefactos donde, más allá de los objetivos iniciales de su creación, fungían como medios de comunicación a distancia, y se estructuró un discurso visual que imponía un ideal de imaginario social que era impulsado por la empresa bananera.

Testimonios de la época permiten percibir que esos afanes de penetración capitalista no sólo correspondían a intereses norteamericanos, sino que provenían también de naciones europeas que deseaban disputar el control de aquellas áreas que se apreciaron como atractivas regiones de explotación. Así sucede con la obra francesa Les cinq Repúbliques de l'Amérique Centrale, editada en 1911. Su autor, el Conde Perigny, quien inicia su escrito destacando la despreocupación existente por el conocimiento que en Francia se tenía de la zona ocupada por las repúblicas de Costa Rica, Guatemala, Honduras, Nicaragua y El Salvador, había realizado un recorrido por la región, escribiendo lo que luego sería la obra mencionada. Destaca allí lo que él determina como la representación errónea que se hace de esos territorios, sin aceptar que se señalen como sus características: la dificultad para habitarlas, el clima extremoso, las condiciones insalubres, su inaccesibilidad, en sí negándose a que se les señale como parte de "una barbarie" clásica de la Edad Media (Perigny, 1911: 3). 
Figura 1. Mapa publicado por la UFCo, delineando lo que se considera como Circuncaribe.

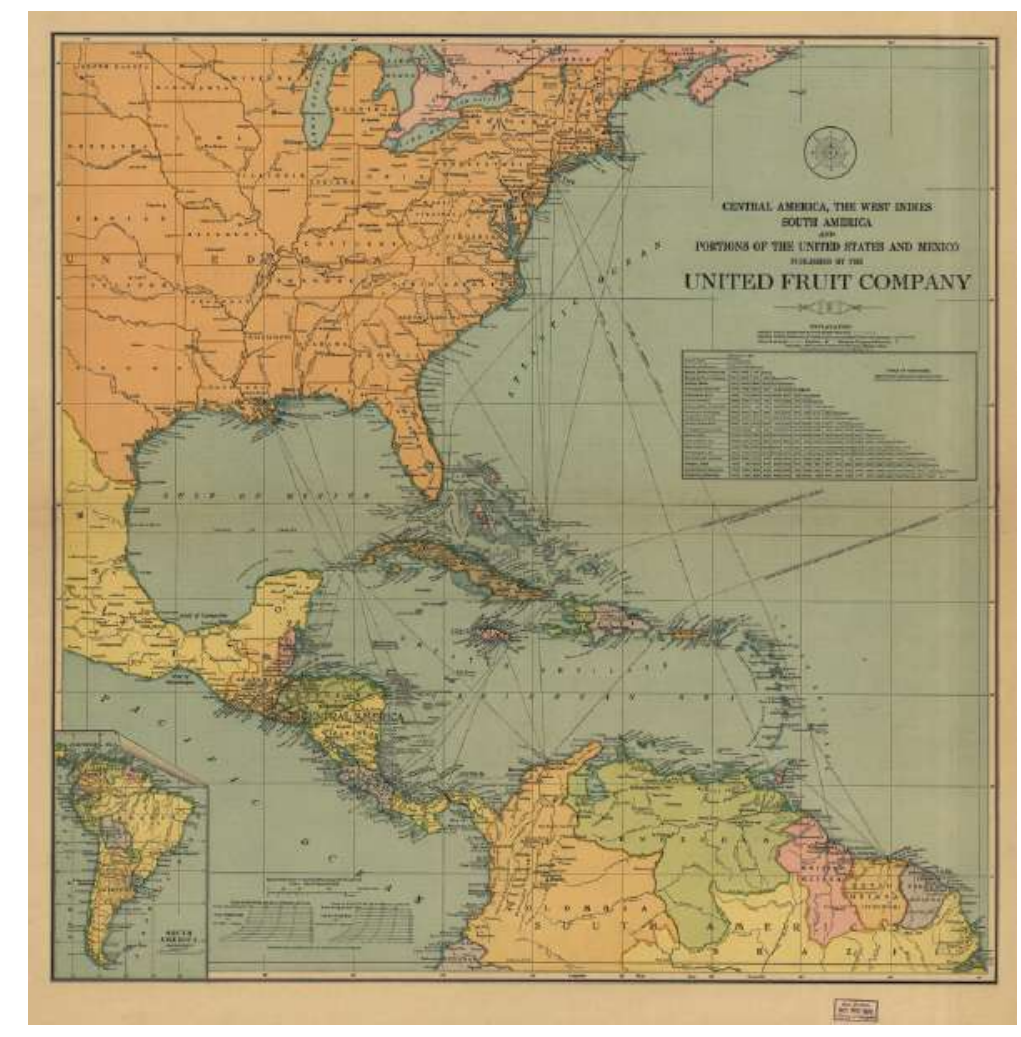

Fuente: Big map blog, 8 de agosto de 2012

A lo largo de su obra contrapone a esa visión negativa una descripción alentadora, en la cual sostiene que las enfermedades han sido controladas; resalta que los caminos ferroviarios facilitan la comunicación, al menos en los lugares principales, y se interesa por descollar que, si bien el calor es en extremo fuerte en las regiones bajas, existen zonas altas donde la atmósfera es agradable. Es decir, se preocupa por ofrecer un panorama alentador a la inversión económica, a tal nivel que en sus páginas pareciera intentar que el propio lector sienta el ambiente benévolo del clima de la zona.

Gracias a la presencia de ambas referencias, la del mapa y la del libro, se puede constatar la construcción de un discurso en el cual la tecnología se antepone como instrumento de justificación por parte de quienes materializaban los proyectos de intereses neocoloniales. Los barcos y los trenes, mencionados en las dos fuentes informativas, eran esgrimidos como parte fundamental de los discursos visuales y textuales. Las propuestas se encaminaban a respaldar aquellas acciones que eran efectuadas por empresas en las que se apoyaba el ideal de modernización en las principales ciudades de la región de América Central y el Caribe.

En muchas de las imágenes del pasado es posible detectar explicaciones sobre cómo los productores de ellas dejaron impregnada su percepción del mundo que les rodeaba. A partir de una imagen es posible reflexionar en torno a los mecanismos que configurarían un determinado imaginario, así como también iluminar sobre 
cuál fue la recepción que tuvieron los lectores de interpretaciones visuales que, al momento de su creación o en momentos posteriores, las observaron. Tomando en cuenta esta circunstancia, dentro de las manifestaciones iconográficas, son las tarjetas postales un vestigio visual de importante presencia. La atención por las tarjetas postales a lo largo de Latinoamérica, la América Central y el Caribe se ha manifestado gracias a la existencia de varias publicaciones, de las cuales debe señalarse su diversidad. Se han identificado, y consultado, ejemplos que van desde aquellos muy sencillos, como A Checklist of Barbadian Postcards, 1898-1930 (Green, 1999), hasta tomos en los cuales se aprecia una elaboración muy cuidadosa, como sucede con el caso de Postales salvadoreñas del ayer/Early Salvadoran Postcards 1900-1950 (Grant, 1999).

Cuando se compra una tarjeta postal se adquiere un artefacto que llama la atención porque representa un hecho, es decir algo concreto, ya sea un lugar o un paisaje, un acontecimiento histórico o una costumbre. Dicho atractivo motiva la adquisición, y el envío, aunque no siempre se lleva a cabo este último paso, o bien, simplemente, la suma de una pieza más de algún coleccionista. Pero en el caso de mandarse/enviarse, se reciben y se leen. Normalmente lo único que se lee es el texto. $\mathrm{Si}$ bien pocas veces se hace una lectura profunda de lo textual, es casi imposible pensar en la lectura de la imagen. Se aprecia el motivo, se mira, mas no se observa; no se le ve en toda su magnitud. Como parte final de ese proceso, regularmente la postal queda relegada en un estante, con algo de suerte queda incluida en algún álbum, o bien puede ser desechada. Las posibilidades de obtener más aportes de las postales son pocas veces atendidas, pese a la riqueza que ellas contienen. Hay mucho que aprender y mucho que decir de ellas; de lo que su contenido encierra y de lo que representa su existencia, habiéndose llegado a desarrollar una historiografía especializada al respecto
(Semmerling, 2004; Stevens, 2005; Fernández, 1994). No obstante, aunque una gran cantidad de las postales latinoamericanas raramente han sido motivo de estudio, habría que consignar que entre los casos existentes muchos sobresalen por su calidad y aportes dentro del proceso de conocimiento histórico y social.

Uno de los ejemplos que vale la pena atender, es el siguiente sobre una nación circuncaribeña. Se trata de la obra intitulada Los orígenes de la República de Panamá a través de las postales, de Vicente Alberto Pascual Landa, la que, en Edición Conmemorativa 100 Años Panamá, fue publicada en 2003. En ella, el autor ofrece datos históricos tanto de la naciente República como de la edición de postales en ese país, resaltando como dato principal la ubicación estratégica de la nación a partir de su ubicación geopolítica. Explica que la idea de un cruce interoceánico provocó que el mercado de las tarjetas postales fuese muy demandado, toda vez que las actividades ligadas a la construcción del Canal de Panamá hicieron necesaria la existencia de ese artefacto como medio de comunicación de los trabajadores, que por cierto fue la razón de su creación allá por el año 1869, en el Imperio Austro-Húngaro. ${ }^{2}$ Lo que no resalta Vicente

2. Nacidas en 1869 durante el Imperio Austro-Húngaro, bajo el gobierno de Francisco José I, la tarea original de las tarjetas postales fue la de cubrir un deseo de comunicación escrita entre personas que se encontraran ubicadas en lugares distantes. Pero pronto, de ser unas simples tarjetas en la que se pudiera escribir un mensaje breve y que fueran de fácil manejo, pasarían a convertirse en medios de comunicación ilustrados que comprendían diferentes aspectos regularmente relacionados con los lugares desde donde eran enviadas. Estados Unidos fue el primer país del Continente Americano que adoptaría, a partir de 1873, el principio de la tarjeta postal. Para un acercamiento a los orígenes y desarrollo de las postales, véase el libro de Aline Ripert et Claude Frère, La carte postale: son histoire, sa fonction sociale, Lyon, París, Presses Universitaires de Lyon/Editions du CNRS, 1983, pp. 17-40. 
Imaginarios del progreso. Representaciones tecnológicas en el Circuncaribe mediante tarjetas postales (1899-1930). El caso de Costa Rica

Alberto Pascual es el hecho de que los inversionistas que promovieron el Canal, franceses, primero y estadounidenses luego, encontrarían en los cartones un medio infalible de propaganda y de respaldo a sus iniciativas capitalistas.

Fue en la última década del siglo XIX que circularon las primeras postales en Panamá. Su impresión se efectuó por la iniciativa de E. Arenz y Verl V. Albert, proceso que por cierto se realizó en Alemania (Pascual Landa, 2003: 16). Las postales eran vendidas en los puertos de los países circuncaribeños, como en Ciudad de Panamá misma o en Colón, así como en Puerto Limón, pero también en la capital costarricense, San José, siendo atractivas por la curiosidad que provocaban los lugares y las escenas desbordantes de exotismo. La evolución editorial de las postales fue notoria en los primeros años del siglo XX, siendo común la reproducción de fotografías de profesionales reconocidos, como Carlos Endara, "quien curiosa y evidentemente no tenía ningún inconveniente en vender sus negativos a diferentes editores sin ninguna restricción o exclusividad", y quien también editaba sus propias imágenes (Pascual Landa, 2003: 17).

En la obra se mencionan otros editores más de postales, destacando Y. Preciado \& Co., M.I. Espinosa B., Arturo Kohpcke, H. de Sola \& Co., The Colon Telegram, Carl Scheleicher \& Schull, A. J. de Simmons (de Colón), Bazar francés y Ascoli Hermanos. Pero un aspecto que llama la atención del ejemplar es que, a pesar de que se ha constatado la existencia de muchas postales producidas por la UFCo, en la obra no es incluida ninguna de tales postales, ni mucho menos se menciona algo puntual sobre ellas. La única alusión a la "Yunai" es la que aparece en el texto de la página 116, en referencia a Louis Irving Snyder Jr., precursor del cultivo y comercialización del banano en Panamá, con fincas en Bocas del Toro, y quien aparece retratado en la postal que se inserta en dicha página. La nota aclara que, posteriormente, Snyder vendió su enclave a la United Fruit Company. ${ }^{3}$

El autor reconoce la posibilidad que ofrecen las postales de conocer y estudiar aspectos históricos y culturales de una nación. En conmemoración del Centenario de Panamá como República se reúnen 180 postales que, según el propio Pascual Landa, "nos ofrecen reflejos de lo que era la vida cotidiana, así como acontecimientos, lugares y aspectos relevantes de diversos eventos que se vivieron en los albores de nuestro acontecer republicano" (Pascual Landa, 2003: 7). No obstante habría que preguntarse que sí, que en verdad se trata de "reflejos" de lo que se vivía, de lo sucedido. Como se ha visto en el desarrollo de esta investigación, dentro del estudio del trabajo editorial de las postales no se ha dado atención a la construcción de imaginarios. Es posible dar fe de la importancia del coleccionismo, de la invaluable información preservada gracias a la pasión por las tarjetas postales. Sin embargo, también queda bien definido que el trabajo sobre el imaginario que sostienen las tarjetas, sobre la utilización de una retórica visual que respalde un determinado proyecto político, social, económico o cultural, es un ejercicio que todavía

3. Snyder Brothers Banana Company, running the "Chiriqui Plantation". The name "Chiriqui" is best known as a very fertile province in western Panama, known for its agriculture. However, "Chiriqui Lagoon" is the name of a large natural bay in Bocas Del Toro province, where the Snyder Brothers Banana Company had their plantation. After working for the Frank Brothers Banana Company, the Snyder brothers started their own banana company around 1888 in Bocas del Toro area of what was then Columbia. Their period of greatest expansion was 1892 to 1896. Minor C. Keith at some point became half-owner in the Snyder Brothers Banana Company, which joined with three other companies to form the United Fruit Company in 1898 (sic). Consulta en: http://www.coins-of-panama. com/checks/ck70-1.html, realizada el 23 de febrero de 2018; 21:42 hrs. 
es necesario desarrollar. Sobre dichos "reflejos" evocados por Pascual Landa, ellos pueden ser cuestionados como efectivas manifestaciones de realidad, pues muy a pesar de que dan testimonio de ciertos elementos que sí existieron; más que reflejos, en el sentido de veracidad, son representaciones elaboradas a través de la captura de símbolos, de objetos, de manifestaciones artísticas que pugnaban por respaldar un determinado ideario, fuese este cultural, político, o de otro tipo. Sobre las notas que aquel autor hace para acompañar a las postales, debe señalarse que únicamente se trata de escritos descriptivos, es decir, que no problematizan alrededor del utilitarismo de sus imágenes contenidas. Como sea, vemos que el libro de postales sobre Panamá es un buen antecedente para mostrar el estado de la cuestión en torno del estudio de postales circuncaribeñas.

\section{Postales ticas, el coleccionismo de los hermanos Castro Harrigan}

Costa Rica fue el país del cual puede decirse que se convirtió en el punto nodal de la penetración capitalista de la UFCo, debido a las condiciones en las cuales se pudo desarrollar el emporio norteamericano, resultado de los contratos benéficos obtenidos por Minor C. Keith; a su situación geoestratégica dentro de la región, así como por la vinculación que tuvo de manera personal con el gobierno tico; luego de haber contraído matrimonio en la década de 1880 con Cristina Castro Fernández, de 22 años, hija del doctor José María Castro -dos veces presidente- y de doña Pacífica Fernández de Castro, autora del diseño de la bandera de Costa Rica (Castro Harrigan, 2006: 63). Eso explica la existencia de sendos libros en los cuales se han presentado las colecciones de las postales costarricenses. Una primera publicación de la que vale hacer mención es: Costa Rica: Imágenes e historia. Fotografías y postales, 1870-1940, volumen I, obra editada en 2005 por los hermanos Álvaro y Carlos Castro
Harrigan. La obra deja huella particular sobre la minuciosa labor que como coleccionistas han desarrollado aquellos hombres. Debe destacarse que al interior del libro se incluyen imágenes que se usaron para promocionar al país. A través del trabajo fotográfico, son rememoradas las ciudades de San José y Cartago, así como los puertos de Limón y Puntarenas. De acuerdo con el prologuista, Oscar Rohrmoser, el libro "muestra la vida rural de nuestros valientes campesinos y su dedicación al trabajo, en la producción de alimentos para sus conciudadanos y para facilitar las exportaciones de café, banano y otros cultivos que eran la base de la economía nacional" (Castro Harrigan, 2006: 1) Él mismo señala el aporte del texto a la historia costarricense, entendiendo dicho legado como una posibilidad de retroceder en el tiempo. Por su lado, los hermanos Castro Harrigan definen que su material responde a la valiosa, aunque simple, tarea de presentar las imágenes al público "tico". Hay un diálogo directo con los receptores, a quienes se pide tomar en cuenta la herencia "de los antepasados" con el fin de conservar y afianzar "nuestra naturaleza de paz y trabajo".

De los cientos de postales que atesora este libro de los Castro Harrigan, destaca la presencia de 47 que fueron dedicadas a la región de Limón. Pero de este subgrupo queremos poner atención en un par de ellas dedicadas a representar la zona de producción bananera. A cada postal se le agregó un sencillo pie de foto, a fin de explicar lo evocado en las postales, sobre los sitios desde dónde se enviaron, así como también comentarios acerca de las fechas de los envíos postales. En algunos casos también traducen los mensajes, escritos normalmente en inglés. Hay otras anotaciones en donde se hace referencia al autor, como sucede en aquella postal titulada "Hospital. Port Limon", donde se especifica que la fotografía es obra de "Horace N. Rudd. Año 1904". Este ejemplo permite señalar que los pies de foto deben 
Imaginarios del progreso. Representaciones tecnológicas en el Circuncaribe mediante tarjetas postales (1899-1930). El caso de Costa Rica

verse como escritos que definen una intención de lo que se quiera que sea leído en las imágenes; pero no sólo eso, también debe tenerse mucho cuidado en que la información ofrecida sea correcta, pues de otra manera se convertirá en obstáculo que impedirá hacer una lectura iconológica de manera adecuada, como pasa allí con el nombre de Rudd, el fotógrafo estadounidense a quien se le nombra como "Horace", cuando a lo largo de la investigación se ha detectado que en realidad se llamaba Harrison Nathaniel Rudd (1840-1917).

Como otro aspecto que es digno de mencionar en torno a los pies de foto, está aquél que corresponde a la postal titulada "Beresem West Farm", y donde los autores escribieron lo siguiente: "Las fincas bananeras progresaron con el advenimiento del ferrocarril y generaron una demanda de mano de obra local". Con esta cita se aprecia una visión de simpatía con la incursión de capitales en Costa Rica, en particular vinculados a la agroexportación y a la infraestructura que se montó de manera paralela. Confirmando una postura que exalta el impulso a la producción bananera, enseguida citan a la reconocida escritora costarricense, Carmen Lyra, de quien son unas líneas más que se integran para acompañar la imagen, y que aquí se presentan:

...y en torno de ellos, por kilómetros y kilómetros, matas de banano que chorrean agua también. Las hojas penden de los tallos como harapos sucios y las chiras rojas hacen pensar en corazones que penden a la intemperie. Van $\mathrm{y}$ vienen los cortadores y los concheros, caen los tallos y el racimo es recibido con todo mimo y depositado cuidadosamente en los mejores sitios (Castro Harrigan, 2006: 116).

La construcción de imaginario elaborada por los Castro Harrigan responde directamente a una intención de alabanza a la Yunai, y para ello tergiversan la información usada. Para ser concretos, se debe explicar que Carmen Lyra, conocida por la constante denuncia que mediante la ficción hace en sus obras contra las empresas bananeras en su país. Lyra: maestra, escritora y activista del Partido Comunista sostiene una denuncia sobre la discriminación, el enriquecimiento de las compañías extranjeras, la explotación excesiva de la mano de obra, el mantenimiento de condiciones laborales y sociales de bajo nivel para los trabajadores y sus familias, como la despreocupación de los gobiernos locales ante la situación nacional, entre lo más destacado (Lyra, 1977: 371-387). Así entonces, incluir tal cita no hace sino desconsiderar el contexto tanto del mensaje literario así como de la propia imagen en la postal, que de manera definitiva responde a otro tipo de retórica visual.

Los Castro Harrigan editan un segundo volumen en el 2006. En él mantienen un mismo tipo de características y comentarios del primer volumen. No obstante, en este caso se puede señalar con mayor intensidad el carácter laudatorio que se da hacia la incursión de capitales extranjeros en Costa Rica. Al hablar de "Limón, la provincia bananera", los autores señalan de entrada que la comunicación hacia esa zona era mucho más difícil, comparándola con la zona del Pacífico, "debido a que no existían puentes ni otros medios para atravesar los ríos caudalosos y los pantanos extensos, por lo que era necesario recurrir a barcas chatas, a manera de balsas" (Castro Harrigan, 2006: 156). Se escribe allí que la distancia de casi 170 kilómetros entre San José y Limón en la época colonial debió recorrerse en un tiempo estimado de un mes, usando carreta hasta Cartago, luego en caballo hasta Turrialba y Matina, subiendo a una balsa hasta la boca del río Matina, para al final recorrer la playa en mula hasta llegar a Limón, pasando por Moín. Esta reseña de las dificultades que debían enfrentarse para lograr el contacto entre la capital del país y 
su costa atlántica sirve de preámbulo a los autores para emitir una exaltación a quien señalan como el hombre que superó la presencia de pantanos y los "asaltos continuos por los indios mosquitos". Así se expresan al respecto: "Con la construcción del ferrocarril al Atlántico, gracias a la inversión y empuje de Minor Cooper Keith, se sanearon los pantanos y las compañías bananeras, en especial la United Fruit Co., se realizaron cultivos extensivos de banano, con fines de exportación" (Castro-Harrigan, 2005: 116). Para cerrar esa alusión a Puerto Limón, comentan sobre el establecimiento de un hospital, el avance comercial de bienes y servicios, acciones que permitieron, de acuerdo con lo enunciado por los editores, que la ciudad de Limón fuera tomando forma y desarrollándose. Destacan la llegada de centenares de trabajadores caribeños y chinos que se establecerían en la zona. Pero al mismo tiempo dejan rastros de la llegada de otros sectores sociales y económicos: "Inversionistas y personas con cargos técnicos o administrativos, llegaron al puerto con sus familias y contribuyeron a elevar el nivel educativo y cultural. Acostumbraban enviar postales a sus seres queridos y esto explica que podamos presentar un gran número de fotografías" (Castro-Harrigan, 2005: 116).

Precisamente las postales son testimonio de la presencia de europeos y norteamericanos, quienes con sus textos consignados en las tarjetas ofrecen un importante conjunto de datos que se suman a los antecedentes para practicar la lectura iconológica. Así se corrobora con la tarjeta "Cortando bananos", en la cual los hermanos Castro Harrigan apuntan en el texto a pie de foto:

Los trabajadores de los bananales realizaban labores agotadoras en un clima extremo, con un futuro incierto. Postal enviada A Manchester, Inglaterra, el 11 de junio de 1904, a donde llegó el 28 del mismo mes a las 3:45 a. m., según consta en el matasellos. El remitente se queja del clima: 'este viaje ha sido un horno. La temperatura en la sala de máquinas es de $114^{\circ} \mathrm{F}^{\prime}$. Fotografía de los hermanos Paynter" (Castro Harrigan, 2005: 174).

Como se aprecia a lo largo de toda la obra de los Castro Harrigan, y aun cuando existe una indicación de las largas jornadas de los trabajadores bananeros, así como es el caso de señalar su "futuro incierto", la visión de los autores es proestadounidense. La tarjeta, desde esa perspectiva, es laudatoria del proceso expansionista del capitalismo norteamericano.

Luego de este apartado, que si bien está basado en la presentación del caso costarricense pero que debe tomarse como representativo de una trayectoria seguida por las postales en el Circuncaribe, en el siguiente se realizará un análisis iconológico sobre unos casos particulares de ese tipo de artefacto visual. Se hará entonces un ejercicio que defina una propuesta sobre las posibilidades que encierra una postal como fuente histórica que, además, corrobora la construcción de un imaginario circuncaribeño de inicios del siglo XX.

\section{Los barcos en la construcción de imaginarios del progreso}

La United fue bastante activa en la producción de artefactos visuales que pueden atestiguar en la actualidad sobre las intenciones que debió tener para promover la iconografía que le representara (Camacho Navarro, 2015). Un ejemplo muy antiguo es el de una fotografía relacionada con la llamada "Flota Blanca" de la UFCo y con Costa Rica, imagen de la cual se tienen unos probables lugar y fecha de captura, ya que en la parte posterior se lee "LIMON 1904 (USA) United Fruit" (Figura 2). Pero no existe referencia precisa sobre el autor, sin que tampoco se tenga la certeza de que el escrito allí integrado sea de la misma época de la toma fotográfica; así como tampoco se tiene 
dato alguno extra que permita facilitar una interpretación amplia de la misma captura fotográfica. Sin embargo, se detecta en la imagen frontal un par de detalles que permiten ofrecer un comentario sobre lo representado. Se muestra un barco que en el tiro de su chimenea tiene pintado el emblema que usó la UFCo para que fuese posible identificarla. Se trata de un logo inconfundible. Además, es visible un texto que a la letra dice:
“-LIMON-", mismo que aparece tanto en la parte superior de la foto como también en el costado delantero del barco, justo debajo de lo que parecen ser unas escotillas del navío. Esos elementos nos dicen, por una parte, que en efecto la United buscó la representación de sus acciones en la zona del Caribe y Centroamérica. Además, la referencia a "Limon" deja una huella plena del contacto con la parte caribeña de Costa Rica.

Figura 2. Fotografía del barco "Limón" (c1904).

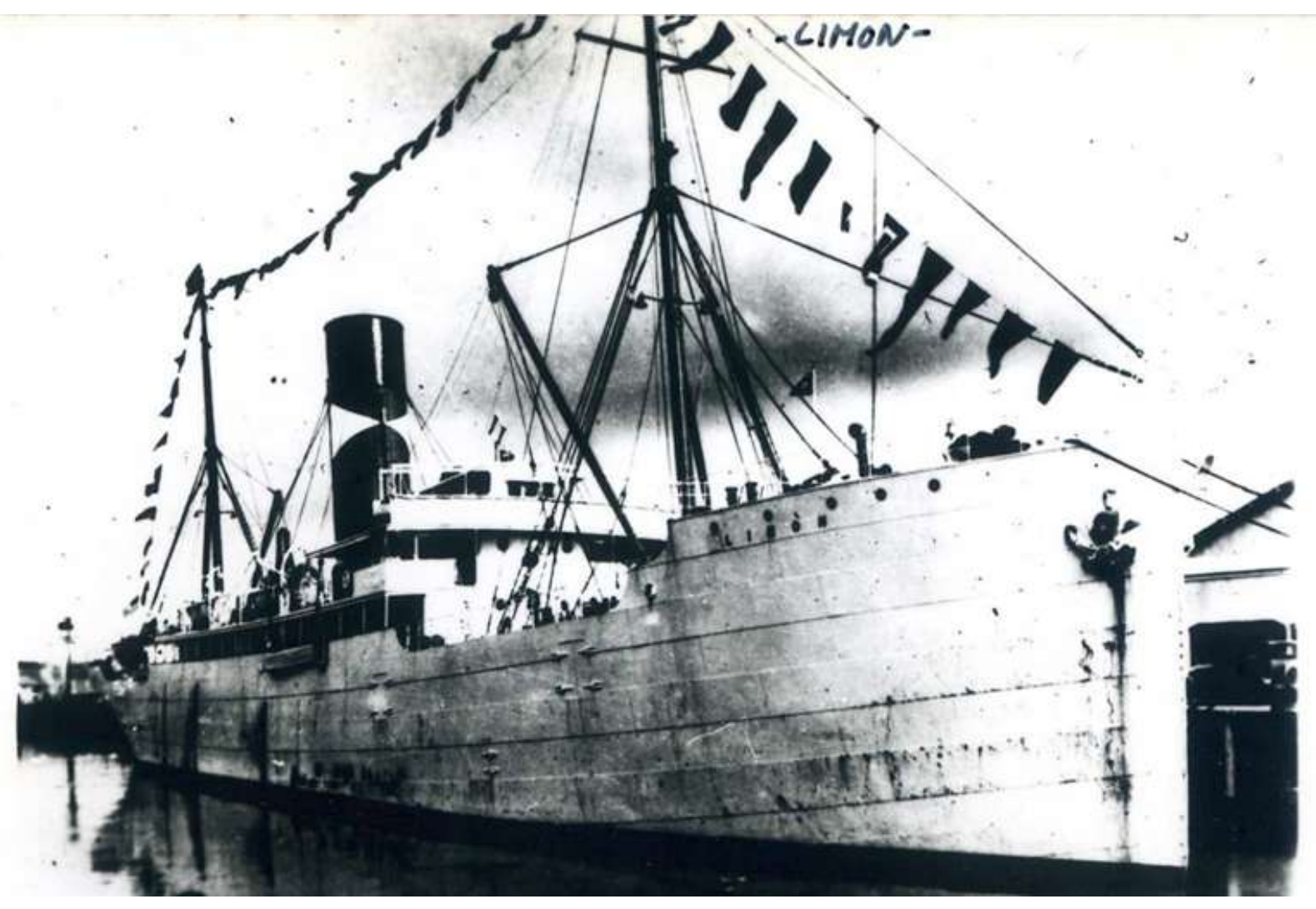

Fuente: Propiedad del autor

Para los posibles "mirones" de aquella época, se trata de una foto en la que se encierra un discurso visual; es decir de una propuesta que a través de imágenes desea ofrecer un mensaje o un punto de vista sobre determinado tema, sobre un objeto o circunstancia que interesa al mismo emisor. Para el caso de la fotografía del barco "LIMON", de la UFCo, ella puede leerse como evidencia de un discurso visual en el que se deseaba resaltar la grandeza de la empresa bananera. En la propia representación se destaca el que la nave ocupe la totalidad de la captura. Hay 
un deseo evidente de darle toda la extensión del formato al barco, a fin de crear una sensación visual de monumentalidad. Mientras que con la referencia a "Limon", que no puede ser otra cosa sino una indicación directa a Puerto Limón, se desea destacar lo que queda aún más patente al haberse remarcado el nombre con un escrito a mano, es decir, el nexo que se mantenía entre la embarcación y la ciudad costarricense, siendo esta población una de las de mayor importancia en la región bananera para la operación administrativa de la frutera norteamericana.

La imagen corresponde a uno de los tres cargueros de la UFCo. El Limón, junto con el San José y el Esparta, fueron los tres primeros barcos hechos ex profeso para la compañía desde su fundación. Para su construcción, el 12 de noviembre de 1903 se firmó un contrato con el compromiso de la armadora naviera, afirmando ésta que serían entregados en un plazo de 7 meses para el primero de ellos, y los demás con intervalos de siete semanas. Los fabricantes realizaron en estos cargueros el primer estudio para sistemas de refrigeración. El Limón se entregó en septiembre de 1904, lo cual permitiría tener dos suposiciones; una, que la fecha de la fotografía se anotó justo en el año de la entrega, o bien que alguien, probablemente quien realizó la anotación, contaba con la información sobre el Limón. Estos tres barcos "pioneros" de la Flota Blanca se mandaron a construir con un tamaño mayor a los cargueros antes existentes, con una capacidad para 10 -y más tarde 18pasajeros, y 45,000 racimos de bananas. Existe información de que en aquel tiempo se hacían bromas sobre el tamaño, afirmando que no habría suficiente carga para llenar su espacio. La situación fue distinta, gracias al éxito comercial. Posteriormente, en 1906, los barcos serían equipados con radio inalámbrico, sabiéndose además que sus cargas llegaron a ser mayores de lo indicado. Por ejemplo, en ese mismo año, el
Esparta lograría un récord al transportar 56,000 pencas desde Limón a New Orleans (Goldberg, 1993: 490 - 491).

Gracias a los datos históricos obtenidos con respecto a la nave, se puede explicar que la antigua fotografía adquiere una importancia que no es fácil de entender sin contar con un marco referencial de la ocasión en que se captura la imagen. Ésta es significativa desde el momento en que representa a uno de los tres barcos con los que la UFCo dio principio a la idea de contar con su propia flota comercial. Se trata de una imagen simple, marcada por la sencillez; sin embargo, debe resaltarse que para el momento en que se capturó alcanzaba un sentido ilustre. Es una representación de la época en que la frutera inició su despunte hacia un destacado sitio dentro de la historia mercantil de las inversiones norteamericanas en Latinoamérica. Como último comentario sobre las naves "pioneras", vale decir que los nombres de ellas correspondían al de tres ciudades costarricenses, Limón, San José y Esparta, lo cual simboliza la estratégica consideración que la UFCo daba al país centroamericano.

Durante décadas, la United continuaría utilizando ese tipo de manifestación visual, hasta convertirlo en una herramienta muy útil para que su representación resultase atractiva, como se aprecia con una foto más del Limón, capturada en $1911 .{ }^{4}$ Así se logró apuntalar uno de los frentes que usó la UFCo para ser aceptada como empresa de confianza, puesto que mediante su arsenal propagandístico convenció a la opinión pública de que, con su existencia, se continuarían ofreciendo "signos de progreso" en la región circuncaribeña.

\footnotetext{
4. Figura 3. Fotografía del Limón, que se encuentra en el libro Going Bananas, p. 492, tomada el 30 de agosto de 1911. Agradezco la atención de la Dra. Liesbeth Francois para reproducir y proporcionarme este material.
} 
Figura 3. Fotografía del barco el Limón, tomada en 1911

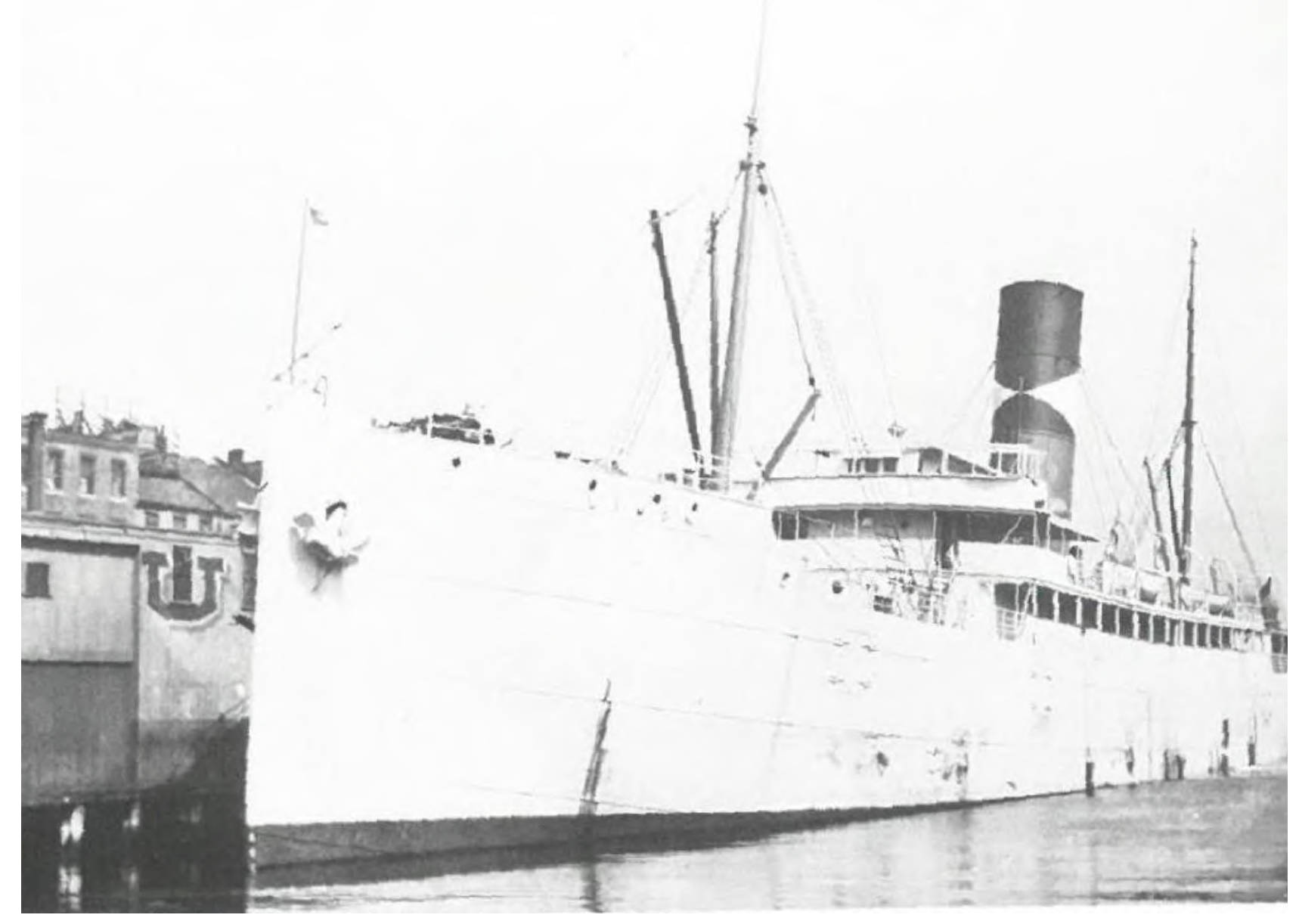

Fuente: Mark H. Goldberg, 1993:492

Ejemplos de los medios que permitieron el éxito de la transnacional, son los miles de anuncios periodísticos, panfletos, y evidentemente los también millares de postales o imágenes fotográficas con las que se representaban a la White Fleet, o "Flota Blanca", como es conocido el conjunto de naves.

El estudio de tales artefactos propagandísticos comprueba que desde muchos años atrás se construía un estereotipo, forma escueta, elemental, de aquella imagen que de manera automática identificaba a los barcos de la poderosa compañía norteamericana como materialización, o garantía, de la transformación del Caribe que impulsaba la UFCo. Al enunciar el estereotipo, el objetivo se encamina a explicar o justificar una determinada situación, en la cual se manifiesta la mirada del otro y la ubicación del yo, que en el caso que nos ocupa se manifiesta con la representación de relaciones de poder, en las cuales queda manifiesta la evidente jerarquía entre culturas en la que domina el yo que enuncia (Pageaux, 2009: 16). Esa intencionalidad queda expresada también con la presencia 
de barcos ilustrados en muchos de los menús que el Steamship Service, al servicio de la propia compañía frutera, ofrecía en las primeras décadas del siglo XX a los turistas que se atendían en los restaurantes que funcionaban en los propios navíos. (Figura 4)

Gracias a la existencia de ese tipo de vestigios visuales, es decir los menús, la United Fruit Company, mediante su Steamship Service, ponía en las manos de sus clientes, justo frente a sus ojos, imágenes cargadas de un abundante simbolismo. Con ellas exaltaron la potencialidad de aquel emporio comercial que, a final de cuentas y directamente, se identificaba con la pujanza de la política económica de los Estados Unidos; y que generó, sin lugar a dudas, un sentimiento de simpatía entre quienes tomaron a la nación norteamericana como modelo de sociedad a seguir.

Figura 4. Imagen de un menú de la UFCo.

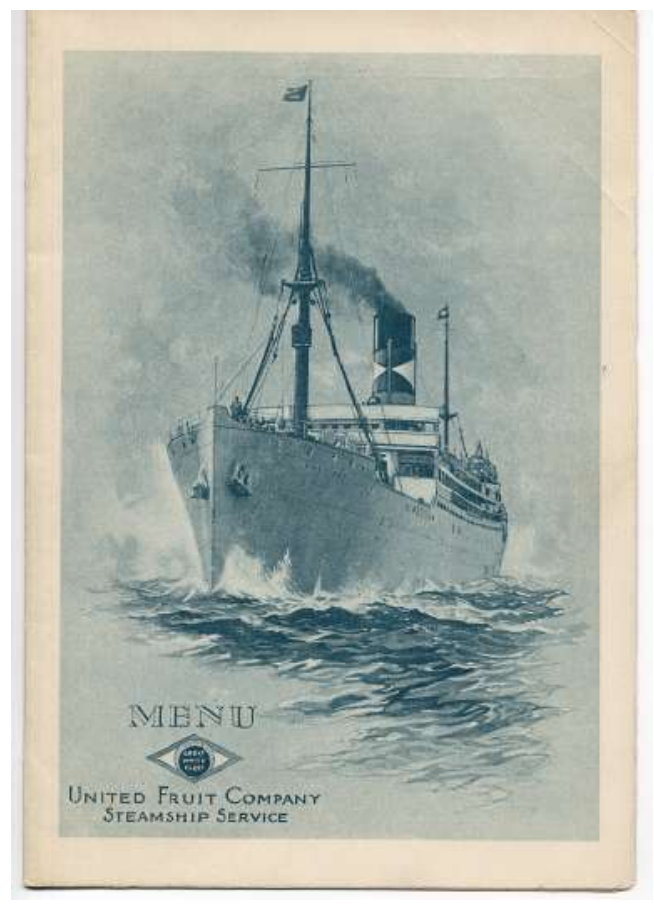

Fuente: propiedad del autor
En esos casos es posible ver, como sucede en muchos otros folletos propagandísticos, imágenes que evocarían una disciplina, reflejada con la formación casi castrense de las embarcaciones que eran representadas en su marcha por el Mar Caribe (Figuras 5 y 6); representaciones alusivas al pasado colonial de viejos imperios instalados en la región, como aquellas en donde aparecen viejos galeones o carabelas, en donde las referencias sirven para contrastar con la modernidad representada por los barcos estadounidenses (Figura 7); o bien imágenes donde el cotejo se realiza poniendo pequeños barcos que representaron al reducido potencial de las naciones circuncaribeñas, en actitudes que simulan una recepción de bienvenida (Figura 9 y 5 ). Tales modelos siempre pueden ser motivo de estudios académicos minuciosos, sin embargo, por el momento, esos especímenes de menús son solamente una parte del marco del análisis que más adelante se realizará de las imágenes contenidas en tarjetas postales.

En los mismos barcos eran vendidas las imágenes, en formato de tarjetas postales, como fotografías enmarcadas, o bien como tomas con posibilidad de encuadrarse posteriormente, para ser parte de las imágenes colgadas en las casas de quienes mostraban con orgullo que habían vivido la experiencia circuncaribeña. Pero también había expendios en los puertos, donde la venta de diferentes productos para el turista o el habitante local era algo cotidiano. Así lo atestigua una postal privada de 1904, tomada precisamente en Puerto Limón, misma en la que se muestra el negocio de H. S. Marshall, quien anunciara su negocio "Evereybody's Newstands" (sic) como lugar de venta de periódicos, tarjetas postales y souvenirs (Castro Harrigan, 2009: 98). 
Figura $5^{5}$ y 6. Folletos propagandísticos del Steamship Service de la UFCo.
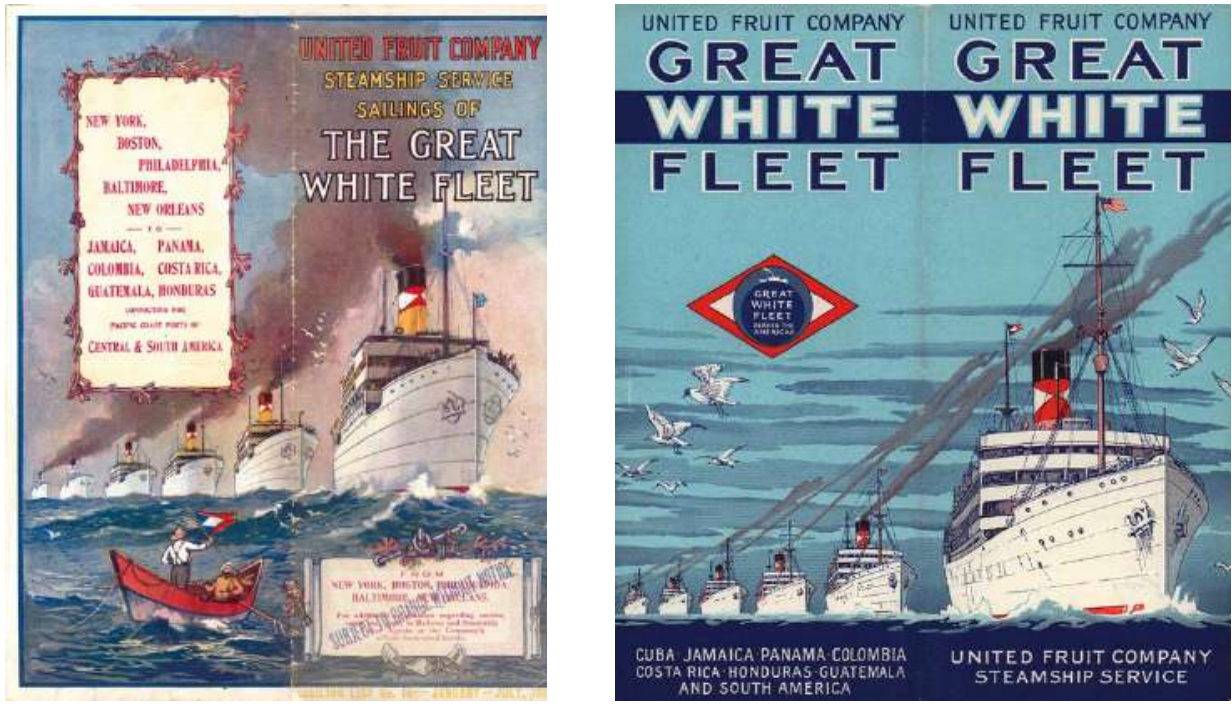

Fuente: Adventures of the

blackgang.tumblr, S.f.

Figura 7. United Fruit Company. Steamship Service. Imagen con carabela representando el atraso español y su contraste con la nueva potencia estadounidense.

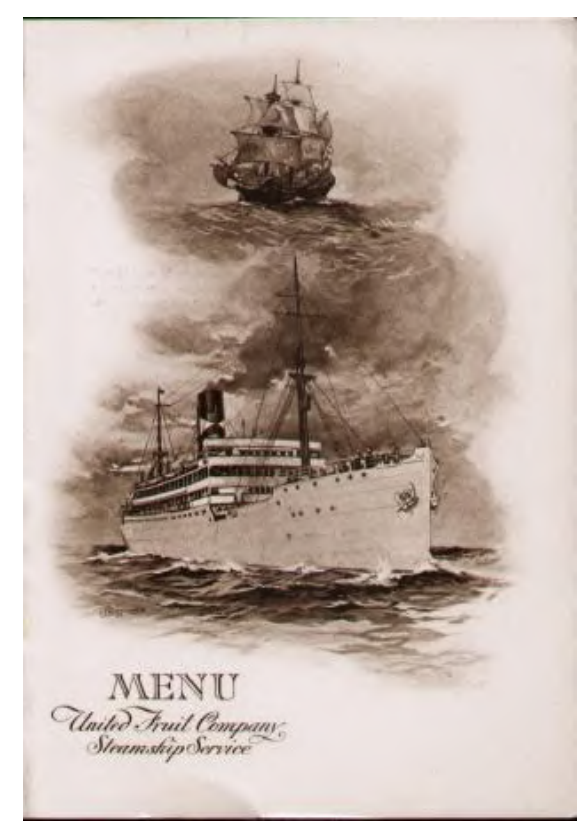

Fuente: iberlibro, s.f.

5. Mi agradecimiento a la colección de Björn Larsson: http://www.timetableimages.com/maritime/images/ufc12a.jpg Consulta realizada el 10 de febrero de 2018; 12:03. 
Figura 8. Menu cover for the United Fruit Company's Great White Fleet in 19241924

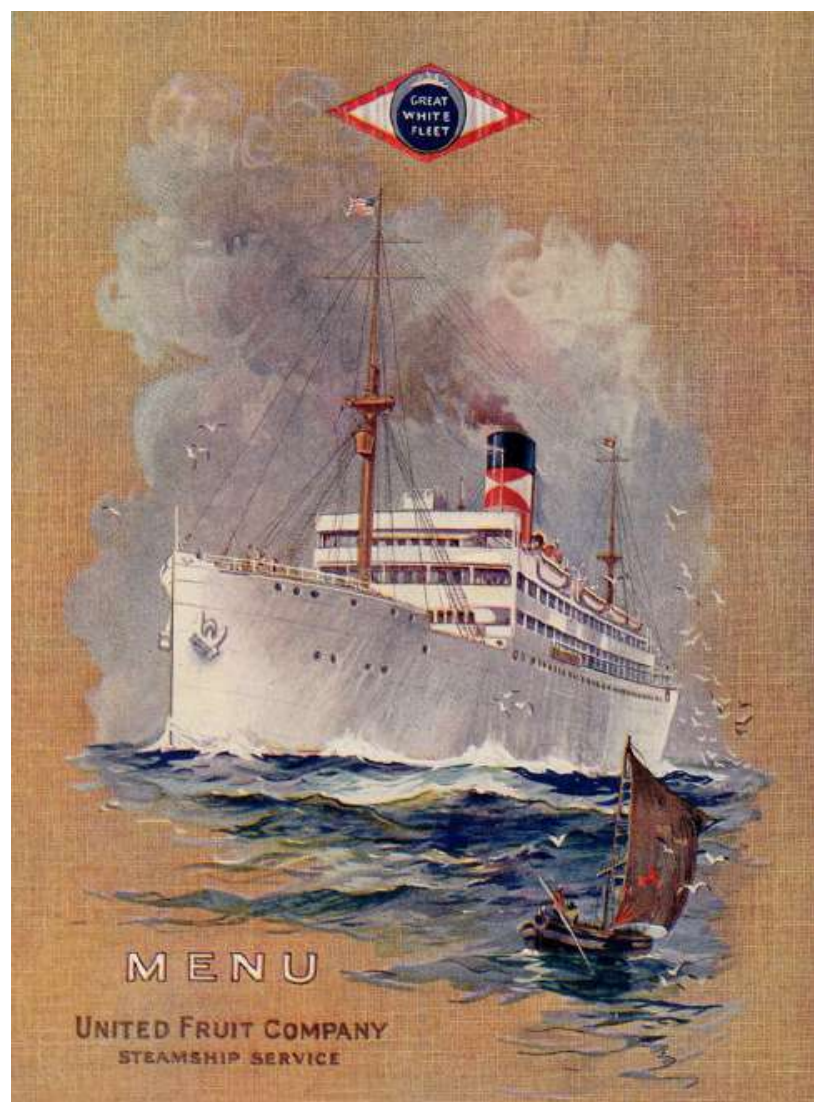

Fuente: Smithsonian Institution Archives, 10 de enero de 2013

La lectura de las imágenes que aquí se insertan, aunque hechas de manera breve, ofrecen indicios sobre las maneras en que los receptores potenciales pudieron tomar una determinada postura hacia los mensajes visuales. Los promotores de la propaganda bananera, entre quienes se encontraban los editores y evidentemente los fotógrafos, dejaron rastros de aquellos públicos en los cuales ellos estaban pensando como posibles "mirones". Tomando en cuenta el origen de los turistas, el idioma en los menús, los símbolos manejados en las imágenes, queda claro que el público observador de las construcciones visuales fue mayoritariamente un receptor occidental, o bien un individuo que comulgaba o aceptaba lo que "Occidente" significaba en ese momento. Si acaso pudiese pensarse en que el público nativo de los países circuncaribeños era el receptor, en la retórica visual se manifiesta una exaltación hacia los centros de poder económico foráneos, y es común encontrar identificación con tal exacerbación. Hay una idealización de la propuesta liberal. No hay una preocupación por enaltecer la potencialidad que los propios habitantes locales tienen, representándoseles a través de pequeñas embarcaciones que contrastan con la "grandeza norteamericana"; o bien minimizando el pasado histórico que se ilustra como atrasado, tal como sucede con la representación decadente de una carabela que señala la época de dominio español (Figuras 7 y 8). En realidad, no es la atención a los lectores locales, ni mucho menos una motivación veraz por atender el interés nacional, o el de la región centroamericana y caribeña, lo que engendra los discursos visuales, sino la necesidad de promover las propuestas ajenas, aquellas provenientes de allende el mar, como único camino para alcanzar el progreso "supuestamente nacional".

Con respecto a las postales en particular, vale comentar que entre los vestigios revisados no es común la aparición de tarjetas enviadas por locales. Es muy raro encontrar ese tipo de ejemplos. Podría decirse que casi siempre se trata de casos en que tanto los remitentes como los destinatarios son ciudadanos norteamericanos -en una gran mayoría- o europeos, predominando entre estos los alemanes e ingleses; aunque aparezcan de manera frecuente franceses y belgas. Así entonces, también en ello se ve reflejado el tipo de público hacia el cual se destinaron los discursos visuales provenientes desde los centros de poder de la UFCo.

\section{Los ferrocarriles en la construcción de imaginarios del progreso}

Como se ha visto de manera indiscutible, de igual manera que la "Flota Blanca" fue un elemento 
Imaginarios del progreso. Representaciones tecnológicas en el Circuncaribe mediante tarjetas postales (1899-1930). El caso de Costa Rica

estereotípico dentro de la creación del imaginario producido por la United Fruit, toda imagen de los ferrocarriles ocupó una posición muy similar. Sus representaciones eran necesarias como símbolos del embate del capital, capaz de echar a andar su poder con la instalación de una red que se ofrecía como garantía del contacto con los diferentes espacios de un territorio que se encontraba aislado. Las imágenes animaban las mentes de los gobernantes que veían a sus proyectos económicos sin posibilidades de movilizar a su población, como tampoco comercializar los productos que se pudieran obtener de la tierra, de esa naturaleza que por encontrarse en un aislamiento total no podía ser transformada ni explotada, con la finalidad, eso se decía, de lograr una transformación plena de toda una sociedad.

El tendido ferroviario por el que corrieron los trenes de la Northern Railway Company fue un elemento que no solamente se promovió como parte del discurso del cambio, de la transformación de Costa Rica por parte de la United Fruit Company. La Northern se forjó como empresa subsidiaria, para así facilitar una conexión con los puertos que permitiera la rápida y eficiente exportación de banano, complementando la infraestructura mercantil de la UFCo. Desde tiempo atrás el FFCC fue usado como imagen cargada de intenciones, precisamente a partir de 1871, al momento en que Minor C. Keith se encargó del trabajo para instalarlo en ese país, y primero como una necesidad de transportar el café. Además de que serviría para mover al que fuera principal producto de la primera parte del siglo XIX tico, también tendría utilidad como respaldo a los proyectos económicos que los gobiernos liberales lanzaron a finales del siglo XIX. Luego de algunos años se convirtió en el adelanto tecnológico que permitiría la movilidad de los millones de racimos de bananos que lograron producirse en los albores del siglo XX.
Hablar de trenes, barcos y bananos es lo mismo que referirse a Keith; ${ }^{6}$ así como hablar de éste era sinónimo del poder en Centroamérica y gran parte del Caribe. Como se expresa en La historia de la tierra del abrazo verde: "El señor Keith, sin lugar a duda, fue el hombre más poderoso que hubo en Costa Rica durante muchos años. En el puerto de Limón su visita se celebraba hasta con juegos pirotécnicos; en contraste, la visita del presidente de la República, en ocasiones, pasaba inadvertida" (Méndez, 1991:7). Pero esa presencia se expandió en todo el Circuncaribe. Su personalidad giraba alrededor de la construcción de puertos, de la instalación de ferrocarriles, así como de la producción del banano. Por tal razón, al hablar del auge comercial bananero, pero en particular del éxito alcanzado entre 1910 y 1913 en Costa Rica, este último año cuando alcanzó una producción de once millones y medio de racimos, la referencia al empresario era algo inminente (Méndez, 1991: 9; Soley, 1926: 284).

La hegemonía de la UFCo se extendió en todo el Circuncaribe. El caso colombiano es un caso sobresaliente, y su contexto ha sido motivo de estudio desde diferentes ángulos, como el que se ha realizado para efectuar una interpretación sobre la influencia de la presencia de la bananera en la literatura canónica latinoamericana.

El ferrocarril del Magdalena estuvo íntimamente ligado a la historia de la United Fruit Company. Este ferrocarril, proyectado y aprobado en 1881, tenía por objeto unir la ciudad de Santa Marta con el río Magdalena. La compañía encargada de la construcción no cumplió su objetivo en la fecha indicada, razón por la cual tuvo varios litigios con el gobierno nacional. Con el propósito de servir los intereses de la compañía bananera, la vía férrea se prolongó al sur, hacia el distrito de Aracataca, llegando a esta población por primera vez en el año

6. Watt Stewart, Keith y Costa Rica, Trad. del inglés por José B. Acuña, San José, Editorial Costa Rica, 1967. 
de 1906. La región bananera, familiarmente conocida por $<<$ la zona $>>$, estaba dividida en cuatro distritos principales: Riofrío, Sevilla, Aracataca y Fundación. La producción de la fruta no solamente estaba en manos de la United Fruit, sino también en manos de cultivadores colombianos a quienes la United compraba el producto de sus fincas. La fruta era transportada por tren hasta el puerto marítimo de Santa Marta y de ahí era llevada por los barcos de la compañía a los puertos de New Orleans y Mobile (Mena, 1972: 380).

Siguiendo con las imágenes, y de regreso con el caso costarricense, como lo muestra aquella que lleva el título de Banana Train (Figura 10), la importancia del ferrocarril se destaca por el impacto que tuvo en las actividades del cultivo del banano. Los escenarios son elegidos con todo el propósito de exhibir la conexión entre las zonas de cultivo y las máquinas que permitirán el transporte de los productos. Se trata de escenas en las que prevalecen pocos elementos, pero donde se puede leer mucho visualmente. En la imagen adjunta, es notable la presencia de bastantes arbustos florecientes, así como también se advierte la inclusión de los racimos del fruto que se sitúan justo al lado de la maquinaria, y detrás de quien pareciera ser el conductor de la locomotora. De esa forma, la naturaleza plantada, y la que ya ha sido explotada, envuelven, por así decirlo, al instrumento con el que se trasladará la plataforma repleta de los productos exportables.

El aparato se ubica en el centro de la toma fotográfica, capturado de tal forma que pareciera romper esa naturaleza que, luego de ser indómita, ha sido sujeta a un proceso de domesticación; es maquinaria con la que se quiere destacar la presencia tecnológica en los procesos productivos. Su chimenea humeante, rasgo que se aprecia al mirar con atención la fotografía, es utilizada como elemento para formar una imagen que busca dinamismo, como si el armatoste tuviera vida. Es el ferrocarril la figura central. Las personas que allí posan bien pueden ofrecer una posibilidad de lectura iconológica que revela la posición privilegiada del hombre "blanco", representación directa de lo occidental, mientras que el hombre "negro" ocupa una postura desenfadada, de cierta confianza, pero a final de cuentas en una posición secundaria, toda vez que se ubica en un segundo plano.

Figura 9. Imagen fotográfica de un tren bananero, sobre la línea entre Puerto Limón y San José, sin datos de fotógrafo, ni fecha, ni origen de la publicación.

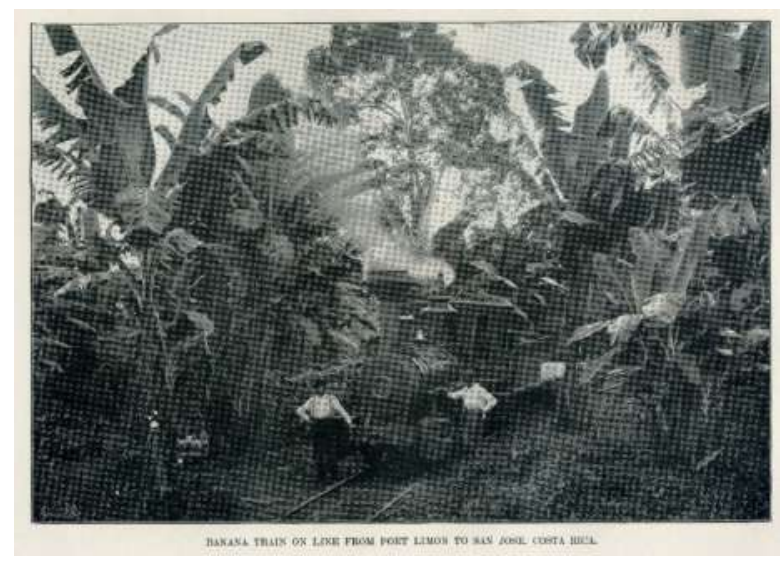

Fuente: Propiedad del autor.

Aun cuando la imagen no ofrece una fecha que permita identificar la época del momento fotográfico, que es uno de los obstáculos que concurren en el ejercicio de lectura iconológica, existen otros vestigios que permiten corroborar que ya desde el siglo XIX se manifestaba un interés por representar a los ferrocarriles como elemento fundamental de una nueva era. Se trataba de un fenómeno ocurrido en toda la América Latina. Un caso ejemplar, entre varios otros, es el trabajo fotográfico del francés Alfred Briquet (1833-1926), quien ya entre 1873 y 1874 deja vestigios de sus capturas del "Veracruz-México Railroad", y a quien pertenece una serie dedicada 
al desarrollo del transporte ferroviario en México (c.1880), patrocinada por el gobierno de Porfirio Díaz con el fin de mostrar el impulso modernizador con que quiso caracterizar a su propio régimen (Briquet, 2017: 4, 43-48, 59, 80). . Pero ese mismo afán de buscar la apariencia modernizadora sucedería también en Costa Rica. Así, tenemos una postal que, aun cuando fue fechada en diciembre de 1901, es posible situarla como creación que corresponde al final del siglo XIX. Se trata de una postal editada por Antonio Lehmann, Librería, San José, titulada "Línea a Limón" (Figura 11 Tarjeta postal fechada el 5 de diciembre de 1901, anverso y reverso).

Figura 10. Tarjeta postal “Línea a Limón”, enviada en diciembre de 1901, anverso y reverso.
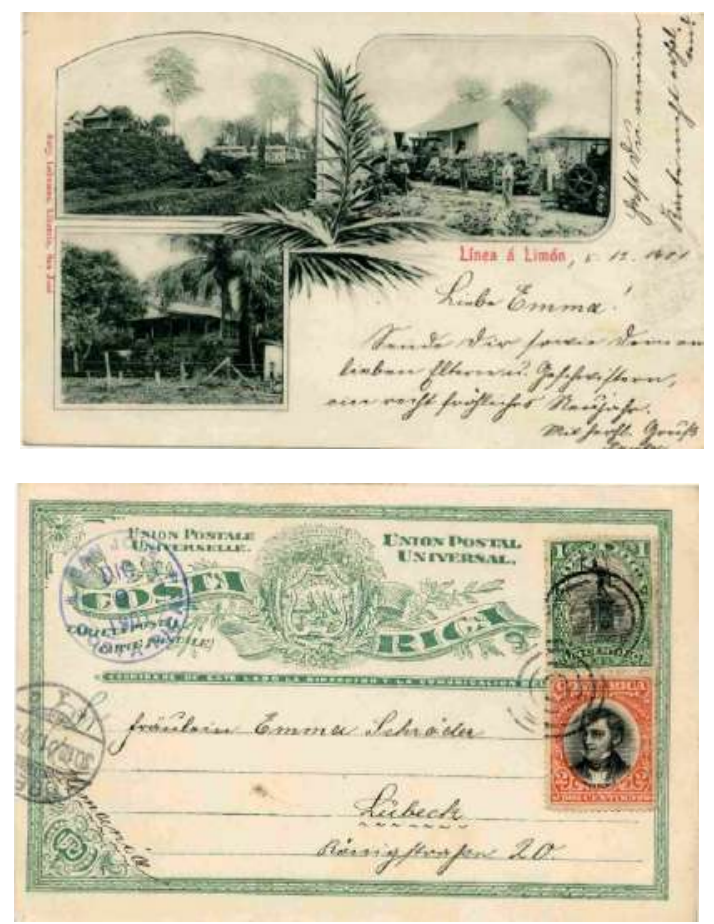

Fuente: Propiedad del autor.

7. Alfred Briquet (1833-1926), catálogo de la exposición que, del 24 de octubre de 2017 al 11 de febrero de 2018, se montó en el Museo Nacional de Arte de la Ciudad de México, México, Secretaría de Cultura, Patronato del Museo nacional de Arte, 2017, pp. 4, 43-48, 59, 80.
Al estilo de las tarjetas de "vistas", la postal enviada a Lübeck, ciudad al norte de Alemania, ofrece tres imágenes que giran sobre la temática de, precisamente, la línea ferrocarrilera al puerto limonense. En las dos fotos ubicadas en la parte superior del cartón, las referencias son directas al tren. Una, la de la izquierda (figura 11), presenta, al igual que en la imagen mencionada un poco antes, al ferrocarril como "sujeto" que ocupa el lugar central.

Figura 11. Detalle izquierdo de la tarjeta postal “Línea a Limón”, enviada en diciembre de 1901.

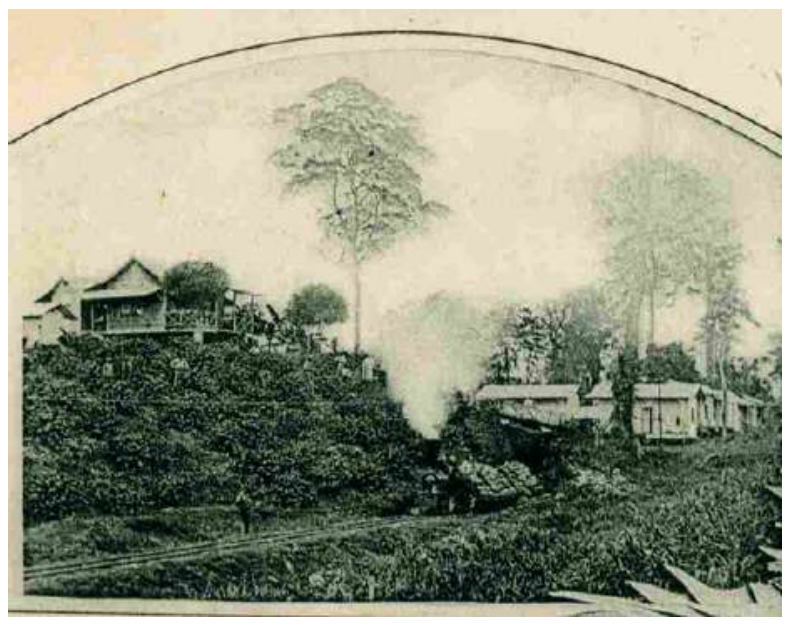

Fuente: Propiedad del autor.

Remolcando una buena cantidad de racimos, y a pesar de que la locomotora debió estar sin movimiento, lo cual es obvio ante la necesidad de ser fotografiada sin que se "barra" la imagen, la chimenea se presenta humeante. Ello debió ser provocado intencionalmente, para dar ese tono de movilidad que también ya se apuntó antes. Por lo que corresponde al segundo recuadro (figura 12), en él aparecen bastantes elementos que exaltan lo significativo de la máquina que, aunque no aparece en su totalidad, es visible en parte, dejando espacio para que se aprecie el tendido vial. 
Figura12. Detalle derecho de la tarjeta postal “Línea a Limón”, enviada en diciembre de 1901.

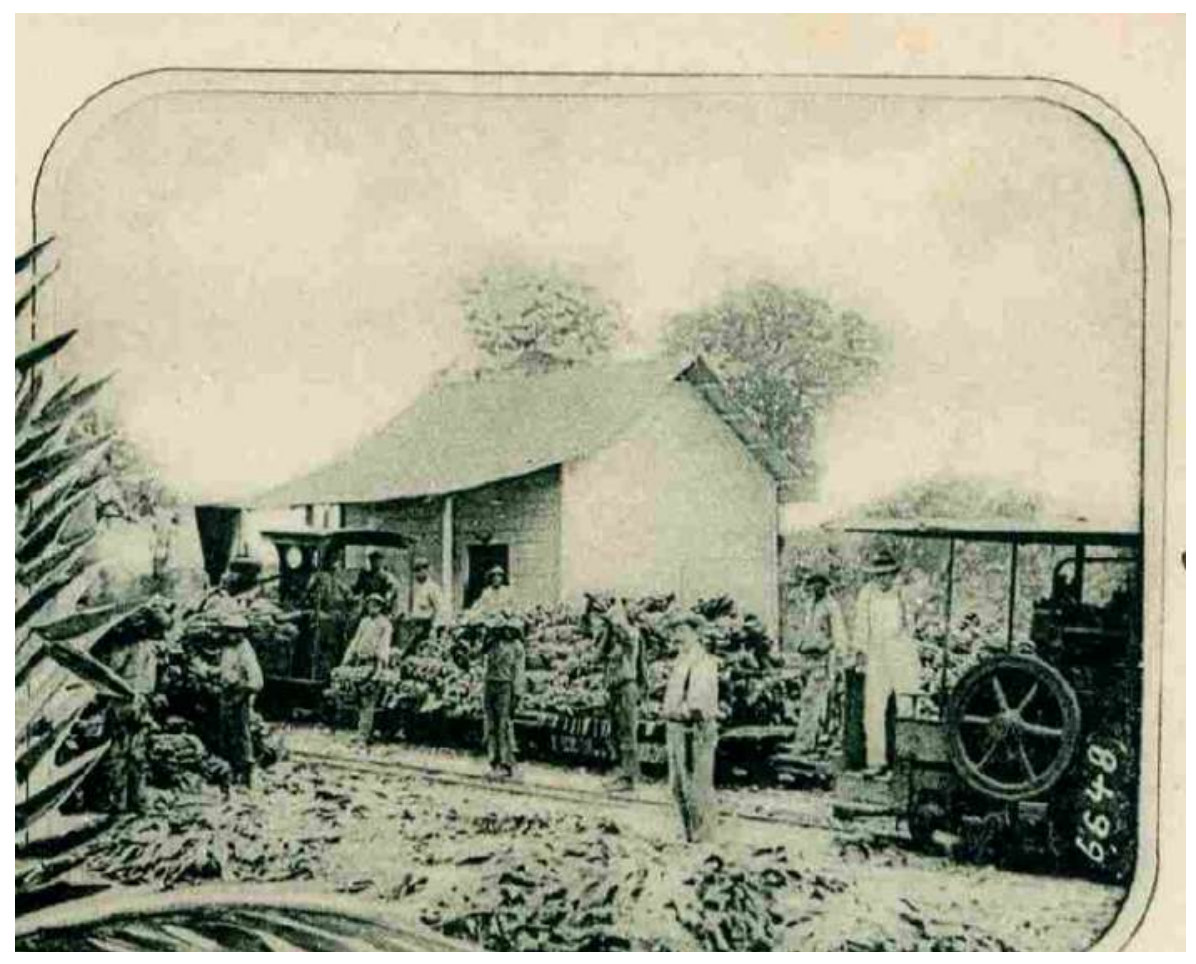

Fuente: Propiedad del autor.

Las plataformas se encuentran llenas de bananos; se observa un par de personas que ocupan el plano delantero, claramente dos "hombres blancos", uno que está en la parte trasera del tren; asimismo se aprecia a un grupo de más hombres, ellos de color, entre los cuales hay quienes sostienen en sus brazos sendos racimos de bananas. También está en la escena otra locomotora, más pequeña, que debió transportar los frutos desde las zonas de plantación, localizadas en partes lejanas a la línea principal de FFCC, hacia los lugares donde se podrían embarcar los racimos en medios de transporte con mayores capacidades.

Como se ha dicho, la realización de esta postal anteriormente descrita se ubica en los últimos años del siglo XIX. Esta propuesta de datación se argumenta mediante la referencia a otra tarjeta postal (López, 2011: 149), perteneciente a la misma serie creada por Lehmann, que con fecha de 1899 se envió a Niza, Francia. Con el título "Memorias de Costa Rica", y referencias puntuales a 3 imágenes en recuadros, Parque de Limón, Puntarenas, y Puerto Limón (Figura 13), este vestigio coincide temporalmente con el año de fundación de la UFCo, dato revelador en tanto que marca el paralelismo entre el primer año de la transnacional y el manejo visual que se da a las actividades bananeras y el ámbito productivo de exportación. Además de mostrar la proyección que las actividades agroexportadoras tenían hacia el panorama internacional, en estos casos particularmente hacia Europa. 
Imaginarios del progreso. Representaciones tecnológicas en el Circuncaribe mediante tarjetas postales (1899-1930). El caso de Costa Rica

Figura13. Tarjeta postal de Antonio Lehmann, "Memorias de Costa Rica", enviada en julio de 1899 anverso y reverso,
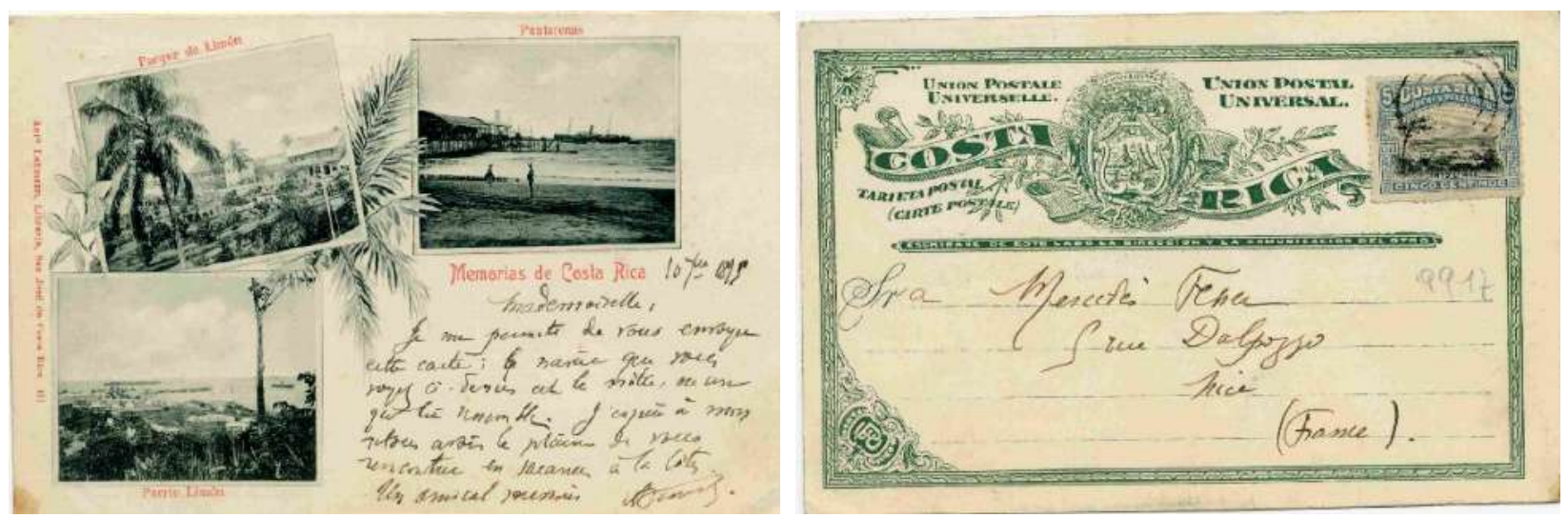

Fuente: propiedad del autor

\section{El banano como protagonista del imaginario de progreso}

La evocación al transporte férreo continuaría por muchos años más. Todavía en la época cercana a 1930, cuando la actividad bananera en la zona atlántica decae, a causa de las enfermedades vegetales en las plantaciones, el sistema de correos movía postales que mantenían esa tarea de encumbrar al ferrocarril como símbolo progresista de las sociedades centroamericanas. En el caso costarricense, parece acentuada esa particular práctica, influyendo el hecho de que se trataba de un país que mantenía una actividad turística muy activa, amén de la posición fundamental como nación encaminada de manera intensiva a la explotación agrícola.

Con la postal llamada "Cargando bananos", también señalada con título en inglés "Loading bananas", la construcción visual es evidente. Editada por la Librería "La Express" de José Montero, San José, su intención se centra en acentuar la monumentalidad de los productos obtenidos en la actividad bananera, así como en la longitud de los vagones que se usarían para el trasporte de aquellos. (Figura 14) En un primer plano apa- rece un conjunto de plataformas. Ellas van al descubierto, pero protegidas en su base por hojas -también de bananos- que tienen la intención de conservar al fruto protegiéndolas del calor solar. Después le sigue otro grupo de vagones, en los cuales serán ubicados los racimos que deben proceder de algunas fincas que no se encontraban sobre la línea férrea principal, por lo cual debían utilizar ramales secundarios. En la parte inferior derecha, precisamente, se ve una parte del tendido vial conectado con alguna otra ruta secundaria. Ocupando el fondo de la toma están las copas de frondosos árboles que son acompañados por el cielo azul.

El banano no podía ofrecer un beneficio futuro sin su movilidad hacia los mercados encontrados fuera de Costa Rica. Por ello son comunes las escenas de numerosas plataformas que acercaban los productos hacia las estaciones donde los grandes vagones de la Northern Railway esperaban para trasladar, desde las plantaciones alejadas de puerto Limón, hasta el lugar donde se continuaría el proceso de envío a mercados internacionales mediante el transporte naviero. Ferrocarril, barcos y bananas son elementos que 
se conjuntaron para impulsar el imaginario de desarrollo que se deseaba hacer presente en la mente de los norteamericanos inversionistas, entre los turistas, que viajaron en su momento por la zona bananera circuncaribeña, entre los propios trabajadores que se encontraban en la zona atlántica, o bien entre los que potencialmente, al ver las escenas, se sentirían atraídos por participar en la aventura del "imperio bananero", donde esperaban encontrar los medios económicos para mejorar su vida, y la de sus familiares. Precisamente la movilidad de turistas en la región también contribuyó en poner al sistema ferroviario en una posición estratégica y, por lo tanto, encumbrada. Su presencia alcanzó altos niveles como instrumento de un despunte de desarrollo nacional.

Figura 14. Tarjeta postal "Cargando bananos", de la Librería 'La Express' de José Montero.

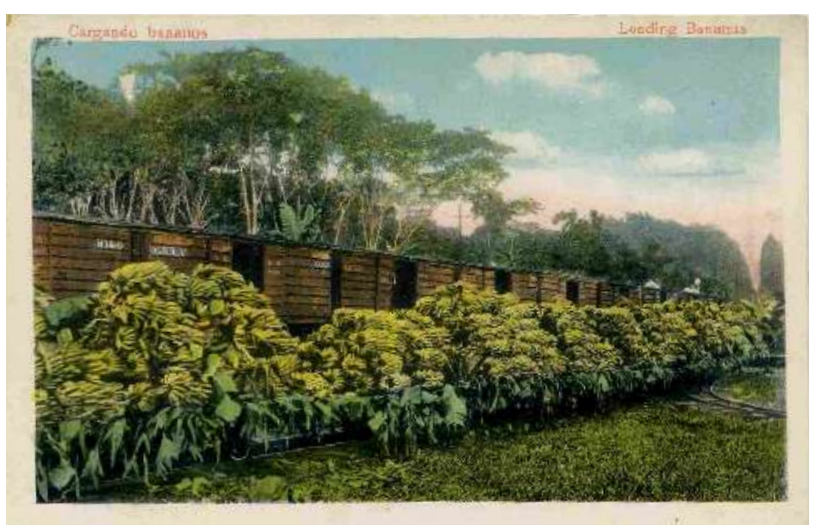

Fuente: Propiedad del autor

Existe una tarjeta postal más con la firma de Montero, el mismo editor antes señalado. El hallazgo de este ejemplar, por fortuna, permite ampliar nuestros comentarios sobre la tarjeta hasta aquí comentada. Se trata de la postal que se titula "Puente de Birris". Su existencia, aunada al ejemplar anterior, y a otro que luego comentaré, permite sostener que se trataba de una serie, es decir un conjunto de imágenes que tenían una secuencia alrededor del tema bananero. También con un copyright a favor de "Librería 'La Express' de José Montero", la postal posee los mismos atributos característicos de la postal "Cargando bananos". Se pone también el título en inglés: "Birris Bridge" y se usa el marco blanco que rodea a la imagen. Esta es una fotografía colorida más. La parte frontal es una representación en la que de forma horizontal se captura la imagen de un tren que tira coches de pasajeros, aunque se aprecian compartimentos que bien pudieron ser para cargar algunas reducidas cantidades de banano, $\mathrm{u}$ otros productos. (Figura 15)

Figura15. Tarjeta postal "Puente Birris" de Librería 'La Express' de José Montero.

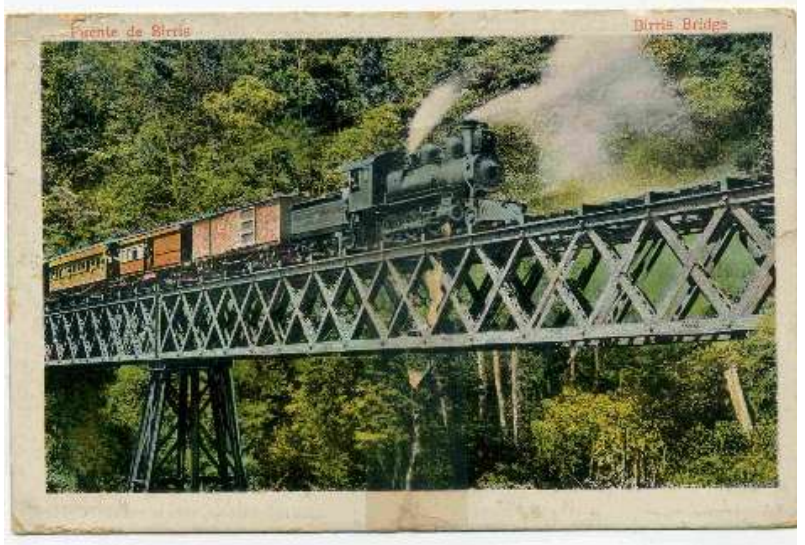

Fuente: Propiedad del autor

Dentro de la misma serie perteneciente a José Montero, se ha localizado una tarjeta más, que el editor tituló "Cargadores de bananos". (Figura 16) Ella contiene una imagen que es resultado de la representación fotográfica también a color de un grupo de cinco hombres. Es común la ausencia de datos que permitan identificar a los creadores de las postales. Los fotógrafos, los empresarios o los impresores pueden quedar como individuos anónimos. Sin embargo, como ya se señaló, en este caso de las postales de la Librería 'La Express' 
Imaginarios del progreso. Representaciones tecnológicas en el Circuncaribe mediante tarjetas postales (1899-1930). El caso de Costa Rica

aparece una identificación de la editora y/o, simplemente, la distribuidora, desafortunadamente sin que exista una posibilidad de asegurar quién fue el fotógrafo. Siendo así, se considera que la intención que pueda descifrarse de la imagen corresponde a los intereses, o a la aceptación de ellos, es decir los editores y distribuidores, o sea al provecho que quiera obtener José Montero, logros expresados a través del discurso visual que se descubre al analizar la composición.

Figura 16. Tarjeta postal "Cargadores de bananos" de la Librería 'La Express' de José Montero.

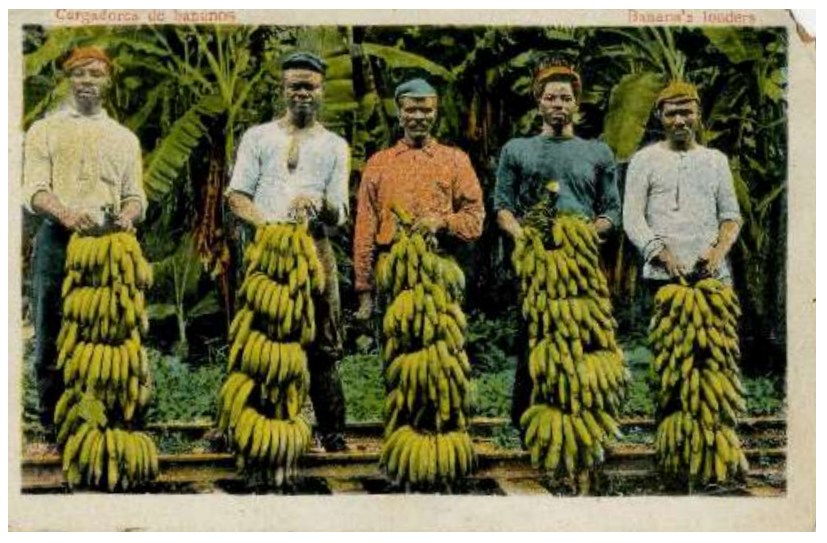

Fuente: Propiedad del autor

Pero de esta tarjeta ahora sólo se quiere mencionar una referencia con la posibilidad de datación. De su reverso podemos decir, antes que nada, que se trata de una parte dividida, práctica común desde pocos años antes de iniciar la década de 1910. Además de contener allí la información ya mencionada de José Montero, está un mensaje escrito el 12 de septiembre; un matasello indica que la postal entró al correo el 13 de septiembre del año 1930 en San José, misma ciudad capital donde fue escrito el texto. También incluye un timbre de "Correos de Costa Rica" por la cantidad de cinco céntimos, dato que se muestra impreso con letra y número, con la leyenda de la "UPU", es decir la Unión Postal Universal, y una fecha que corresponde a la de emisión del ejemplar, siendo 1929. La parte central de éste, producido por "Waterlow \& Sons Limited London", la ocupa una imagen arquitectónica del edificio de "Correos y Telégrafos" costarricense. Gracias a este ejemplar es posible datar el tiempo en que aproximadamente circularon las dos primeras referidas postales de Montero, es decir, finales de la década de 1920.

Sin extendernos en este caso, dentro del análisis sólo se destacará que el primer plano que se atendió durante el momento fotográfico es el del banano. El protagonista es el fruto que se encuentra en proceso de ser transportado. Ligando este factor a nuestra postal principal se hace evidente que los cinco hombres que aparecen -lo que ya se mencionó- no son lo importante, aunque la impresión inicial fuese esa. En la imagen fotográfica se exalta a los bananos. Pero además el ferrocarril logra ocupar también un espacio de primer orden. Las vías, muy a pesar de que se encuadran en la imagen gracias a un forzamiento logrado por el fotógrafo, dan sentido a la existencia del producto. Sin ese elemento, que representa o simboliza el aprovechamiento de la tecnología, la riqueza natural no tendría sentido. En resumen, el banano es el producto que explica el objetivo de la fotografía y de todas las imágenes presentadas, así como la intención del artista y del difusor de la imagen. Así mismo, tomando a Montero como individuo que expresa los ideales occidentales, vinculado además a la tendencia liberal por sus actividades comerciales, queda claro que el hombre de color, "el otro", tiene un lugar muy ajeno a los intereses de quienes exaltan la comercialización del plátano. Los hombres de origen afrocaribeño quedan muy al margen de la propuesta de imaginario; su aparición en la postal sólo refleja el carácter utilitario de los trabajadores. Ellos son mucho menos importantes que el producto que con su esfuerzo logran producir: son simple y llanamente mano de obra. 
Lo anterior hace pensar que la proyección occidental del "otro", pueda ser espacio en el que participan los propios individuos que pertenecen a tal "otredad". Es decir que José Montero juega un papel de reproducción del estereotipo con que es visto todo el Circuncaribe, un territorio bananero por excelencia, mirada que se construyó, y se adaptó a toda la región, a partir de la influencia del imaginario promovido por los extranjeros (Pérez, 2011). Aquí entonces se confirma que las postales son materiales que contienen expresiones de cómo los ojos occidentales han percibido y representado al mundo.

\section{CONCLUSIÓN}

Las locomotoras (Aguayo, 2003) y los barcos (Goldberg, 1993) funcionaron, a través de sus representaciones visuales, como alicientes para adherirse a una convicción desarrollista, operando como gestores silentes de un prometido progreso que - imaginariamente - beneficiaría no solo a la ciudad de Puerto Limón, a su provincia, y a Costa Rica, sino a toda la región circuncaribeña por completo. Ya desde finales del siglo XIX y hasta el primer cuarto del siglo XX, cada uno de los habitantes, turistas y empresarios, se encontrasen o no en la Provincia de Limón, verían a estos medios de transporte ilustrados iconográficamente como los responsables directos del éxito logrado en una labor que redituó grandes ganancias: la producción del banano. Ferrocarriles y navíos son elementos tecnológicos relacionados a las actividades bananeras; teniendo en particular sus representaciones un enlace fundamental con el interés que mantuvo la United Fruit Company por sentar un imaginario de éxito a través de imágenes. Trenes y barcos son piezas fundamentales de una propuesta ilusoria de impacto progresista; de una promesa de futuro brillante que la empresa norteamericana anunciaba de manera optimista como resultado de sus actividades comerciales, pero que aun en nuestros días brilla por su ausencia.
Con todo, es posible entender cómo las empresas creadoras de las imágenes que se integraron a las tarjetas postales del Circuncaribe, como se ha visto a través del caso costarricense, ponían en las manos de sus clientes, justo frente a sus ojos, iconografías cargadas de un abundante simbolismo. Con ellas exaltaron la potencialidad de aquel emporio comercial que, a final de cuentas y directamente, se identificaba con la pujanza de la política económica de los Estados Unidos; y que generó, sin lugar a duda, un sentimiento de simpatía entre quienes tomaron a la nación norteamericana como modelo de sociedad a seguir. Pero todo quedó en eso, en ser únicamente "imaginarios del progreso".

\section{REFERENCIAS BIBLIOGRÁFICAS}

Adventures of the blackgang.tumblr. (s.f.). United fruit company great white fleet 1926. Recuperado de: http://adventures-of-the-blackgang.tumblr. com/post/3628393088/united-fruit-companygreat-white-fleet-1926 el 27 de enero de 2018.

Aguayo, F. (2003) Estampas ferrocarrileras, México, Instituto José María Luis Mora.

Alfred Briquet (1833-1926). (2017). Catálogo de la exposición que, del 24 de octubre de 2017 al 11 de febrero de 2018, se montó en el Museo Nacional de Arte de la Ciudad de México. México: Secretaría de Cultura, Patronato del Museo nacional de Arte.

Big map blog. (28 de agosto de 2012). United Fruit Company Map of Central America (1909). Recuperado de: http://www.bigmapblog.com/2012/ united-fruit-company-map-of-central-america-1909/

Black, J. (1998). Maps and History. Constructing Images of the Past, New Haven, Estados Unidos: Yale University Press.

Camacho-Navarro, E. (2015). Como se pensó Costa Rica. Imágenes e imaginarios en tarjetas postales, 1900-1920, México, Ciudad de México: CIALC/ UNAM. 
Imaginarios del progreso. Representaciones tecnológicas en el Circuncaribe mediante tarjetas postales (1899-1930). El caso de Costa Rica

Castro-Harrigan, Á. y Castro-Harrigan, C. (2005). Costa Rica: Imágenes e historia. Fotografías y postales, 1870-1940. Volumen 1. San José, Costa Rica: Editorial Técnica Comercial. Prólogo de Oscar Rohrmoser Volio.

Castro-Harrigan, Á. y Castro-Harrigan, C. (2006) Costa Rica: Imágenes e historia. Fotografías y postales, 1870-1940. Volumen II. San José, Costa Rica: Editorial Técnica Comercial.

Fallas, C. L. (1941). Mamita Yunai, Santiago de Chile, Chile: Nascimento.

Fernández-Tejedo, I. (1994). Recuerdo de México. La tarjeta postal mexicana 1882-1930, Ciudad de México, México: Banco Nacional de Obras Públicas (Banobras).

Goldberg, M. H. (1993). Going Bananas. 100 Years of American Fruit Ships in the Caribbean, New York, Estados Unidos: The American Marine Museum Foundation.

Grant, S. (1999). Postales salvadoreñas del ayer/ Early Salvadoran Postcards 1900-1950, San Salvador, El Salvador: Banco Cuscatlán.

Green, M. (1999). A Checklist of Barbadian Postcards, 1898-1930. Barbados: s.l., s.e.

Handy, J. (1996). "Enfrentándose al pulpo. Nacionalismo económico y cambio político en Guatemala y Costa Rica en la década de 1920". Mesoamérica, 17.

Iberlibro. (19 de noviembre de 2001). Menu, united fruit company steamship service "t.s.s. calamares" Luncheon Menu, March 8, 1921. Recuperado de: https://www.iberlibro. com/MENU-UNITED-FRUIT-COMPANYSTEAMSHIP-SERVICE/1112519968/bd, el 6 de enero de 2018.
Larsson, B. (2001-2018) Maritime Timetables Images. Recuperado de:

http://www.timetableimages.com/maritime/ images/ufc12a.jpg. Consulta realizada el 10 de febrero de 2018.

Lyra, C. (1931). Bananos y hombres, Recuperado de:

http://www.lospobresdelatierra.org/textos/ lyrabananosyhombres.html, el 24 de febrero de 2018.

Lyra, C. (1977) Relatos escogidos, prólogo, selección y notas de Alfonso Chase San José. San José, Costa Rica: Editorial Costa Rica.

López-Hurtado, M. (2011). La tarjeta postal como documento. Propuesta de un sistema de análisis documental, en Martínez-Comeche, J.

A., Marcos-Recio, J. C., Sánchez Vigil, J. M. Actas del VIII Seminario Hispano-Mexicano de Biblioteconomía y Documentación: Información y Documentación: investigación y futuro en red. Llevado a cabo en las instalaciones de la Universidad Complutense de Madrid, Madrid: Universidad Complutense de Madrid. Facultad de Ciencias de la Documentación. Departamento de Biblioteconomía y Documentación.

Mark H. Goldberg, Going Bananas. 100 Years of American Fruit Ships in the Caribbean, New York, The American Marine Museum Foundation, 1993, p. 492.

Mena, L.I (1972). La huelga de la compañía bananera como expresión de lo «Real Maravilloso» americano en Cien años de soledad. Bulletin Hispanique, 74(3-4), 379-405.

Méndez-Porras, G. (1991). La historia de la tierra del abrazo verde, Guápiles, Costa Rica: s. e. 
Pageaux, D.H. (2009). América latina / Europa: miradas cruzadas. Aleph, 23, 15-30.

Pascual-Landa, V. A. (2003). Los orígenes de la República de Panamá a través de las postales. Edición Conmemorativa 100 Años Panamá. 2a ed. Bogotá, Colombia: Editorial Vicente Stamato.

Perigny-Comte, M. (1911). Les cinq Repúbliques de l'Amérique Centrale, París, Francia: Pierre Roger et Cie, Editeurs.

Plowman. D. S. (2001-2008). Numismática de Panamá. Recuperado de http://www.coins-ofpanama.com/checks/ck70-1.html.

Ricordi, H. E., Gasteazoro, C. M., Jované, J. A., Gasnell, C., Camazón, D. R; del Cid, M. A., Candanedo, J. A. (1974). Panamá y la frutera. Análisis de una confrontación económico-fiscal. Una batalla contra el colonialismo, Panamá, República de Panamá: Editorial Universitaria de Panamá.

Ripert, A. y Frère, C. (1983). La carte postale: son histoire, sa fonction sociale, Lyon. París, Francia: Presses Universitaires de Lyon/Editions du CNRS.
Smithsonian Institution Archives. (10 de enero de 2013). Los viajes tropicales de George C. Wheeler Parte I. recuperado de:

https://siarchives.si.edu/blog/tropical-travelsgeorge-c-wheeler-part-i, el 20 de febrero de 2018.

Semmerling, T. J. (2004). Israeli and Palestinian Postcards, Presentation of National Self, Austin, Estados Unidos: University of Texas Press.

Soley, T. (1926). Historia Monetaria de Costa Rica, San José, Costa Rica: Imprenta Nacional.

Stevens, N. D. (1995). Postcards in the Library: Invaluable Visual Resources. New York, Estados Unidos y Londres, Inglaterra: The Haworth Press.

Stewart, W. (1967). Keith y Costa Rica. San José, Costa Rica: Editorial Costa Rica. 